\title{
Sustainable spatial development: a story of Novosibirsk and Krasnoyarsk agglomerations
}

\author{
Irina Usmanova ${ }^{1 *}$, Nadezhda Ligaeva $^{1}$, Olga Kuznetsova ${ }^{1}$ \\ ${ }^{1}$ Institut of Ecology and Geography, Siberian Federal University, Svobodny ave. 79, 660041 \\ Krasnoyarsk, Russian Federation
}

\begin{abstract}
Under the conditions of market- economic reforms that have been taking place in Russia over the past 30 years, the sectoral and territorial structure of the country's economy has changed dramatically. The economy of some regions, that were successful during the Soviet times sagged and failed, while other regions experienced an actual economic take-off. This paper discusses the main aspects of the spatial organization of the Russian Federation and the development of the Novosibirsk and Krasnoyarsk agglomerations, which are the largest economic centers of Western and Eastern Siberia. To answer the main question of the study- whether thirty years of economic restructuring in the country could affect the leading position of Novosibirsk and make Krasnoyarsk the new regional leader of Siberia, the authors perform the comparative socio-economic analysis of both agglomerations.
\end{abstract}

\section{Introduction}

The Russian Federation is the largest country in the world by its area. This fact has led to emergence of wide variety of natural, historical and socio-economic conditions for the development of its regions. Thus, a significant gap between different federal subjects of Russia in terms of living standards has formed. The gap between the backward regions of the country and regions with the average level of economic and social development took shape back in the Soviet period.

However, the contrast between successful and problem areas has increased significantly in the conditions of market economy system. On the one hand, there is a number of entities with a very high territorial concentration of population, labor resources and production, that have stood out over the past years of transformations. These regions are often oriented towards external markets. On the other hand, there are regions with a lack of development prospects within the framework of the economic model that has developed in the country. Uneven development of regions and districts is also a fairly frequent occurrence in other countries [1]. The weakening of ties of domestic economy increases the isolation and creates the mood of separatism among the backward regions. This causes a high level of social

\footnotetext{
${ }^{*}$ Corresponding author: usmi59@mail.ru
} 
tension in society and complicates the process of territorial control. These circumstances $\mathrm{m}$ the government of the Russian Federation pay more attention to the territorial development of the country. The spatial organization of society has been the subject of many scientific studies, government strategies and programs. One of the tools for improving the spatial structure is the formation of regional growth centers in the form of large urban agglomerations. The idea of using such centers for the spatial structure development was firstly put forward about fifty years ago by a number of authors [2, 3].

\section{Basic documents for the territorial-economic development management of the Russian Federation}

Management of socio-economic development of the Russian Federation is based on a system of documents, including strategies, concepts, Federal laws and Presidential decrees. One of the main documents in this sense is the Federal Law N 172-Fz of 28 June, 2014 "On Strategic Planning in the Russian Federation" [4], which provides the development plan for both industry-specific and regional programs, since the country's socio-economic system is not only a complex of industries, but also a territorial-economic system. Clause 26, Article 3 of the Federal Law N 172-Fz of 28 June 2014 "On Strategic Planning in the Russian Federation" states that "The Spatial Development Strategy of the Russian Federation is a strategic planning document that defines the priorities, goals and objectives of the regional development of the Russian Federation. Its main aim is to maintain the stability of the resettlement system in the Russian Federation" [4].

The content and basic concepts of regional development are defined by such documents as "The Spatial Development Strategy of the Russian Federation for the Period up to 2030" [5], The Decree of the President of the Russian Federation "On Approving the Fundamentals of State Policy of Regional Development of the Russian Federation for the Period up to 2025" [6] and others. These documents outline the main trends, problems, goals, objectives and fundamental principles of spatial development of the Russian Federation.

The whole host of documents such as territorial planning schemes, strategies for the socio-economic development of economic regions, macro regions, constituent entities of the Russian Federation and various sectoral programs are based on The Spatial Development Strategy.

\section{Socio-economic differentiation of Russian regions}

According to the above-mentioned documents, one of the main trends in the spatial development of the Russian Federation is the increasing population and production concentration in some of its regions. These are primarily 40 large urban agglomerations and four mineral raw centers, which are associated with the production of hydrocarbons and diamonds.

The importance of the natural resource factor for the territorial development is decreasing in developed countries [7], but is still relevant for Russia. The concentration of information and innovations is the most important factor for the development of all agglomerations [8].

The territorial population and production concentration is an inevitable consequence of the economic law of the productive forces' development. On the one hand, this situation contributes to the growth of economic efficiency, but on the other, creates a number of acute socio-economic problems. According to The Draft Concept of The Spatial Development Strategy [9], one of the main problems is so-called "compression" or "condensation" of 
Russia's economic space around Moscow and regional capitals, along with the dissemination of the economic "periphery", where demographic and economic significance has sharply decreased over the years of market reforms. That has led to a current situation, where eight or ten federal subjects of Russia produce $80 \%$ of the country's GDP and appear to be the leaders both in amounts of paid taxes and economic development rate, while the economy of the remaining 70 entities stagnates or degrades.

There are several types of territories in the Russian Federation, which have evolved in different directions in terms of socio-economic development. Along with the successfully developing regions, there are vast territories with a low level of economic and social development. The interregional difference is so significant that "the backward regions of the Russian Federation will need not even tens, but hundreds of years to reach the level of modern and economically developed areas. This indicates the presence of contrasts of intercontinental scope within one country (akin to the contrasts between European and African countries)" [9]. The modernization of these regions and solvation of its' problems is impossible without external help from federal center. The present situation is an obstacle to the balanced spatial development of the Russian Federation.

According to the theory of "Four Russias" by Zubarevich, a Professor at the Geographical Department of Moscow State University, federal subjects and cities of the Russian Federation can be divided into four different groups, based on its' level of socio-economic development, prospects and factors of growth. The future development direction of these entities depends on the group it belongs to [10].

The backlog of many federal subjects of the Russian Federation from the regions with the average socioeconomic conditions is a big problem for the holistic and harmonious development of the country. It carries the threat of social conflict, separatism and political instability. As an example, it is enough to mention the excessive, hypertrophic development of Moscow with its growing housing, environmental and transport problems against the population outflow from peripheral regions, that slows down and impedes its' development.

An effective spatial development policy should help to ensure equal opportunities for the realization of the constitutional rights and freedoms of Russian citizens throughout the Russian Federation. Its main goal is to: “...ensuring sustainable and balanced spatial development of Russia, aimed at reducing interregional differences in population's quality of life" [5].

\section{City agglomerations as supporting centers for the territorial development}

One of the main directions of Russian socio-economic development is balanced spatial development, in particular, "the integrated development of Siberian and Far Eastern territories and the population consolidation in the Eastern regions of Russia" [11], that became very important since Siberia's share in national economy and total population of the country decreased quite noticeably during the reform period (Figure 1).

One of the goals of the Spatial Development Strategy of Russia is the progressive development of current centers of economic growth and creation of new, large, perspective agglomerations [12]. The target scenario is aimed at the rapid population and economic growth in both old and new large urban agglomerations, that will allow to redistribute the resources for the development of the backward regions. 


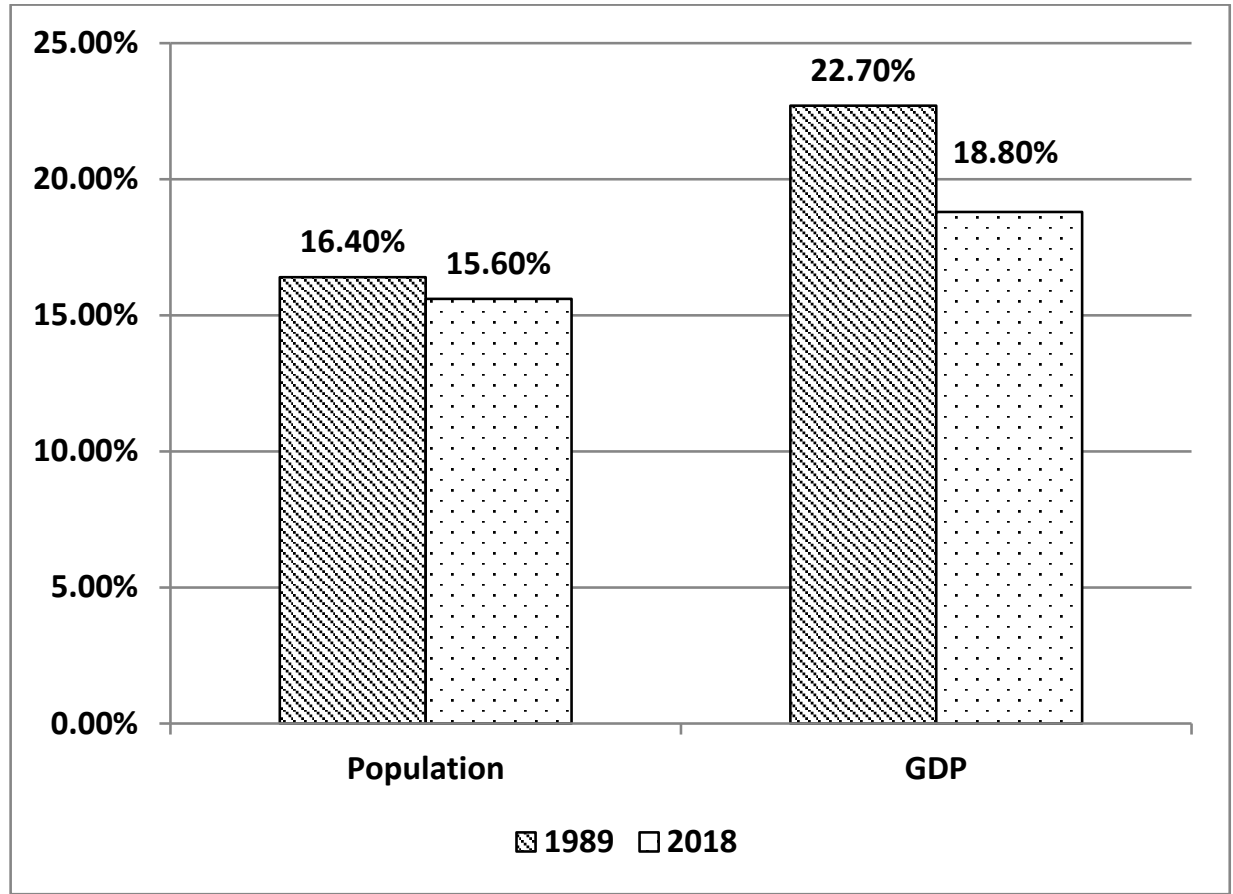

Fig. 1. Siberia's share in total population of Russia and its contribution to GDP in 1989 and 2018

According to the Spatial Development Strategy the number of such centers of economic development should be increased by two times [5]. Currently, there are around 40 urban agglomerations in the Russian Federation that can be called the economic centers. When considering Siberian cities, these are primarily the cities with over one million people population like Novosibirsk, Krasnoyarsk, Omsk, etc. Novosibirsk and Krasnoyarsk are the economic centers of West Siberian and East Siberian economic regions and the core of agglomerations of the same name.

\section{Comparison of the Novosibirsk and Krasnoyarsk agglomerations}

In order to answer the main question of the study and understand whether Krasnoyarsk can become a leader of Siberia, we need to compare the agglomerations of both cities.

According to the All-Union Population Census, there were 1.16 million inhabitants in Novosibirsk in 1970 [13]. Krasnoyarsk became a million -person city more than forty years later, in 2013 [14]. By the end of the Soviet era, Novosibirsk have already become the center of an actively forming agglomeration- the largest economic center of Siberia, its regional capital. Since 2007 the development of Novosibirsk as a part of the agglomeration had become a part of the new "Master Plan of Novosibirsk" for the period up to $2050[15,16]$.

In Soviet times, Krasnoyarsk was inferior to Novosibirsk for all economic indicators. However, over the thirty - year reform period, the Russian economy has changed significantly. This transition has been accompanied by a deep restructuring of economy's sectoral structure. Russia has become a part of the world economy, some of its products are now in demand on the external markets and are traded at world prices, bringing high incomes 
to the manufacturing companies and the regions of its' origin. The agglomeration processes on the territory around Krasnoyarsk were also intensified at this time.

The Krasnoyarsk agglomeration is one of the eight emerging agglomerations of Siberia with the elaborated development concept. The first visible output of this concept was the "Territorial Planning Scheme of the Krasnoyarsk Urban Agglomeration", created in 2008 [17]. In 2018, The Scheme was updated with a planning perspective for the period up to 2038 [18].

Have the role of the Novosibirsk and Krasnoyarsk agglomerations changed in the conditions of the market reforms?

The contribution of Krasnoyarsk Krai to Russia's GDP is more significant compared to Novosibirsk Oblast- in 2018 the shares of these regions were 2,5\% and 1,5\% respectively. The preponderance of the mining industry in Krasnoyarsk Krai is especially remarkable $4.1 \%$ compared to $0.5 \%$ in Novosibirsk oblast. Krasnoyarsk Krai is also 1,6 times ahead of Novosibirsk oblast in terms of Gross Regional Product (GRP) per capita. Along with the absolute indicators, it is also necessary to consider the structure of GRP in both regions. Krasnoyarsk Krai is a more resource-rich region- the mining industry makes $21 \%$ of its GRP volume and is practically absent in Novosibirsk oblast. The share of manufacturing industry in both regions also differs considerably- 31\% of GRP in Krasnoyarsk Krai and 13\% in Novosibirsk oblast.

Krasnoyarsk Krai is mainly aimed at raw materials export and manufacturing industries. Service sector is not a big part of its economy. For example, transport and trade make up only $12 \%$ of its GRP volume, while in the Novosibirsk oblast these sectors contribute $31 \%$ to the region's economy. Novosibirsk Oblast, deprived of the raw material factor is actively using its scientific capacity- the professional, scientific and technical activities sector makes up 5\% of its GRP. This type of activities is insignificant in Krasnoyarsk Krai [19].

Therefore, there is a question whether the leading economic position of Krasnoyarsk Krai can help the Krasnoyarsk city to become the new regional leader of Siberia. The comparison of socio-economic and geographical indicators of both agglomerations can help to answer this question.

The total area of the Novosibirsk and Krasnoyarsk agglomerations is almost the same26 and 24 thousand square kilometers respectively. $48 \%$ of population of Krasnoyarsk Krai is concentrated in the Krasnoyarsk agglomeration. The total population of the Krasnoyarsk agglomeration is estimated at 1,4 million people and it is two thirds of population of the Novosibirsk agglomeration, which has 2,1 million inhabitants. $77 \%$ of population of Novosibirsk Oblast is concentrated in the Novosibirsk agglomeration.

The territorial concentration of production in Krasnoyarsk Krai is lower compared to Novosibirsk Oblast, as there is another major industrial center Norilsk, located in the North of Krasnoyarsk Krai, with its Mining and Metallurgical Company "Norilsk Nickel”. Norilsk produces $25-30 \%$ of GRP volume, Krasnoyarsk contributes $38 \%$, while the share of Novosibirsk in the economy of Novosibirsk Oblast is almost 80\% [20].

The reduced share of the Krasnoyarsk agglomeration in its region's economy and its difference in the population aspect is mainly a consequence of such natural causes as the size of these entities. Krasnoyarsk Krai is 13 times larger than Novosibirsk Oblast by the land area. Density of the economic space of the Krasnoyarsk agglomeration is much lower than that of the Novosibirsk, which can be also a consequence of housing density of these two entities- 57 and 82 individuals per square kilometer respectively [21]. The regional specialization affects the sectoral structure of agglomerations (see Figure 2). 


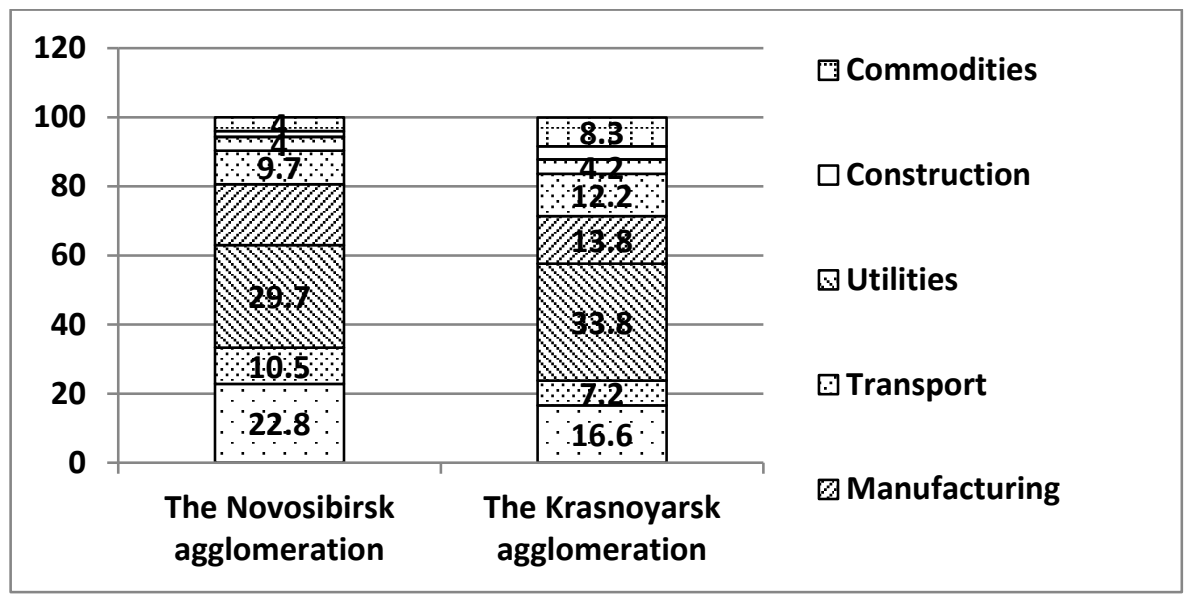

Fig. 2. The sectoral structure of the Novosibirsk and Krasnoyarsk agglomerations

According to The Institute for Urban Economics (IUE) [21], The Gross Metropolitan Product (GMP) of the Novosibirsk agglomeration is $15 \%$ higher than GMP of the Krasnoyarsk agglomeration (with 0.8 and 0.7 trillion rubles respectively). The economic activity is also higher in Novosibirsk than in Krasnoyarsk- its' contribution to GMP is $94 \%$ and $82 \%$ respectively.

In the Soviet period, Krasnoyarsk had many military factories, while Novosibirsk was one of the country's major center for the military equipment production, a center of the Military-Industrial Complex (MIC). The enterprises of the military-industrial complex were greatly reduced in both cities in the course of economic reforms, accompanied by the conversion of military production. The Krasnoyarsk economy has remained afloat due to the Krasnoyarsk Aluminum Smelter, the second largest aluminum smelter in the world. Novosibirsk was not that lucky in this respect, however, after the MIC closure, the service sector evolved rapidly here.

The city became an intermediary between China and the rest of Siberia in the trade with Chinese goods. There was no such a growth factor in Krasnoyarsk due to its' geographical location. The fact that Novosibirsk Oblast was involved in the trade with China has led to the rapid development of transportation sector, the growth of small and medium enterprises, a more diversified economy with more advanced service sector than in Krasnoyarsk Krai and Krasnoyarsk itself [22].

It is important to mention, that one of the most important scientific and educational complexes in Russia-Akademgorodok was established in Novosibirsk during this period. Akademgorodok (Academy town) is the third largest scientific center in the country. It includes 43 academic institutes, 7 international research institutions, 39 higher education institutions, a medical academy etc. Almost half of higher educational institutions of Siberia and the Far East are concentrated in Novosibirsk.

As for the tourism industry, the Novosibirsk agglomeration also takes the lead- the sector is much more developed here. During the Soviet times Krasnoyarsk was a city closed for foreigners and opened up for visitors only in 1991. Long-term isolation has not benefited the development of the tourism infrastructure. 


\section{Conclusions}

Overall, this paper looked into the sustainable spatial and regional development of two Russian cities - Novosibirsk and Krasnoyarsk - as well as their agglomerations. We showed Novosibirsk that was founded much later than Krasnoyarsk during the construction of the Trans-Siberian Railway at the end of the $19^{\text {th }}$ century has developed rapidly. By the end of the period of Soviet industrialization, Novosibirsk was ahead of Krasnoyarsk both in terms of population and industrial potential. The thirty years of market reforms in the country have certainly brought immense changes to the economic grounds for the agglomerations. However, the Novosibirsk leadership has not been undermined.

The comparative analysis of the socio-economic development of both agglomerations led to the conclusion that Krasnoyarsk does not stand a big chance of becoming the regional leader of Siberia. Among the main factors, explaining why Krasnoyarsk takes the second place are: the natural resource factor, a less favorable economic-geographical position, a more inertial economy, a lack of labor force within the Krasnoyarsk agglomeration and a smaller domestic market. The leading role in this part of Russia belongs to Novosibirsk and the situation is unlikely to change in the near future. All these findings might be of a special interest to the local and state politicians as well as stakeholders and urban planners.

\section{References}

1. World Bank Group, https://openknowledge.worldbank.org/handle/10986/5991 (2009)

2. W. Strielkowski, T. Veinbender, M. Tvaronavičienè, N. Lace, Economic ResearchEkonomska Istraživanja, 33(1), 788-803 (2020)

3. P. Krugman, Journal of Political Economy, 99, 483-499 (1991)

4. Federal Law N 172-Fz of 28 June 2014 "On Strategic Planning in the Russian Federation", http://static.kremlin.ru/media/acts/files/0001201406300016.pdf(2014)

5. Government of the Russian Federation, http://static.government.ru/media/files/UVAlqUtT08o60RktoOXl22JjAe7irNxc.pdf (2019)

6. Decree of the President of the Russian Federation, http://kremlin.ru/acts/bank/41641 (2017)

7. M. Porter, The Competitive Advantage of Nations: With a New Introduction (1990)

8. T. Hägerstrand, Papers and Proceedings of the Regional Science Association, 16(1), 2742 (1966)

9. Ministry of Economic Development of the Russian Federation, http://xn---7sbbhnbqial1ebd4mma.xn--p1ai/uploadedFiles/files/Kontseptsiya_SPR.pdf (2016)

10. N.V Zubarevich, Regiony Rossii: neravenstvo, krizis, modernizaciya (2010)

11. Government of the Russian Federation, http://government.ru/info/6217/ (2008)

12. N.V Zubarevich, Pro et Contra, 16, 135-152 (2012)

13. HSE Institute of Demography, http://www.demoscope.ru/weekly/ssp/rus70_reg2.php (1970)

14. Russian Federal State Statistics https://www.gks.ru/storage/mediabank/Ejegodnik_2019.pdf(2019)

15. Council of deputies of Novosibirsk, https://novo-sibirsk.ru/dep/construction/plan/ (2007)

16. S.V. Filonov, Balandinskiye chteniya, 9(2), 237-240 (2014)

17. The Krasnoyarsk Krai Ministry of Construction and Architecture, http://www.krskstate.ru/dat/bin/art_attach/1103_arh.pdf(2008) 
18. Krasnoyarskgrazhdanprojekt, http://minstroy.krskstate.ru/dat/bin/art_attach/11219_tom_ii._castx_1.pdf (2018)

19. Russian Federal State Statistics Service, https://gks.ru/bgd/regl/b19_14p/Main.htm (2019)

20. The Institute for Urban Economics (IUE), http://www.urbaneconomics.ru/sites/default/files/ekonomika_rossiyskih_gorodov_i_agl omeraciy__vypusk_2_noyabr_2017.pdf(2017)

21. The Institute of Urban Economics http://www.urbaneconomics.ru/sites/default/files/vgp_is + sue3.pdf(2017)

(IUE),

22. I.H. Usmanova, N.A Ligaeva, O.A Kuznetsova, IOP Conference Series: Materials Science and Engineering, 753, 042001 (2020) 